\title{
Prevalence of Aac(6’ )-Ib-Cr and Qepa Genes among Quinolone Resistant Uropathogens Isolated from Asymptomatic Female Students of a Northern University on Nigeria
}

\author{
Ezeh PA ${ }^{1}$, Tende $\mathrm{M}^{1}$, Bolaji RO ${ }^{1}$, Olayinka $\mathrm{BO}^{1}$, Menegbe $\mathrm{BY}^{2}$ and Igwe $\mathrm{JC}^{3^{*}}$ \\ ${ }^{1}$ Department of Pharmaceutics and Pharmaceutical Microbiology, Faculty of Pharmaceutical Sciences, Ahmadu Bello University, Zaria, Nigeria \\ ${ }^{2}$ Department of Accident and Emergency, Ahmadu Bello University Teaching Hospital, Zaria, Nigeria \\ ${ }^{3}$ Department of Pharmaceutical Microbiology and Biotechnology, Gombe State University, Gombe State, Nigeria
}

"Corresponding author: Igwe JC, Department of Medical Microbiology, Department of Pharmaceutical Microbiology and Biotechnology, Gombe State University, Gombe State, Nigeria, Tel: +234 8069430222; E-mail: igwejames42@yahoo.com

Received date: March 04, 2017; Accepted date: September 14, 2017; Published date: September 18, 2017

Copyright: $@ 2017$ Ezeh PA, et al. This is an open-access article distributed under the terms of the Creative Commons Attribution License, which permits unrestricted use, distribution, and reproduction in any medium, provided the original author and source are credited.

\begin{abstract}
Introduction: Quinolone resistance are commonly chromosomally encoded but plasmid mediated quinolone resistance (PMQR) has been reported. This study aimed to assess the prevalence of aac (6')-Ib-cr and qepA genes among quinolone resistant uropathogens isolated from asymptomatic female students of a northern university.

Method: A total of 400 urine samples were examined, uropathogens were isolated from the urine samples, identified using Microgen GNA-ID kit and tested for antibiotics susceptibility by the modified Kirby-Bauer disc diffusion method. DNA were extracted from quinolone resistant isolates and presence of aac(6')-lb-cr and qepA genes were determined using PCR.

Result: A total of 148 Enterobacteriaceae were isolated from the urine samples positive for bacteriuria. The organisms consisted mainly of Klebsiella spp. (19.6\%), Acinetobacter spp. (19.6\%), Enterobacter spp. (17.6\%) and Escherichia spp. (11.5\%). Identification to species level revealed that the most prevalent organisms were Acinetobacter baumannii (13.5\%), Klebsiella oxytoca (11.5\%), Serratia marcescens $(8.1 \%)$, Klebsiella pneumonia (7.4\%), Enterobacter agglomerans (7.4\%), Salmonella arizonae $(6.8 \%)$ and Escherichia coli (6.8\%). Antibiotics susceptibility showed that $18 / 148(12.2 \%)$ of the isolates were resistant to quinolones. The highest level of resistance to Quinolones was seen with Ciprofloxacin (12\%) followed by Pefloxacin, Norfloxacin and Levofloxacin $(6 \%) .10(55.6 \%)$ of the isolates showed increased susceptibility to the same quinolone antibiotics used for antibiotic susceptibility testing to which they were resistant after plasmid curing indicating that resistance was carried on plasmids. Molecular analysis on the 10 cured isolates showed the amplification aac(6')-lb-cr gene and qepA gene on electrophoretic gel. $70 \%$ of the isolates expressed the gene aac $\left(6^{\prime}\right)-I b-c r$ of 482 bp and $70 \%$ of the isolates expressed the gene qepA of $199 \mathrm{bp}$. The report shows that there is an occurrence of PMQR among the study population.
\end{abstract}

Keywords: Uropathogens; Female students; Quinolone resistant; aac(6')-Ib-cr gene; $q e p A$

\section{Introduction}

Quinolones and Fluoroquinolones are broad-spectrum antimicrobials highly effective for treatment of a variety of clinical and veterinary infections. Their antibacterial activity is due to inhibition of DNA replication [1]. The first quinolone, nalidixic acid (possessing a naphthyridonecore), was introduced into clinical use in 1962 [2]. In the mid-1980s, ciprofloxacin, a quinolone (with a quinolone core) that had a wider spectrum of in vitro antibacterial activity, particularly against Gram-negative bacteria, first became available clinically [3]. Since then, newer agents with increased antimicrobial activity against Gram-positive pathogens have been developed, but ciprofloxacin still has great activity against Gram-negative pathogens has been $[4,5]$.

Quinolones exert their antibacterial effect by preventing bacterial DNA from unwinding and duplicating [6]. The majority of quinolones in clinical use belong to the subset fluoroquinolones, which have a fluorine atom attached to the central ring system, typically at the 6position or C-7 position.

Antibiotic resistance is a growing global problem and some of these are due to overuse of antibiotics by humans [7]. Resistance to high levels of antibiotics has been ascribed in most instances to the presence of plasmid [8-11]. Several works have associated resistance to quinolones with plasmids and some organisms that show this type of resistance are Escherichia coli, Proteus mirabilis, Klebsiella pneumoniae and Psuedomonas aeruginosa [9,12-15]. The increasing frequency of ciprofloxacin resistance in Enterobacteriaceae has been associated with the increasing prevalence of $P M Q R$ genes.

Quinolone resistance are commonly chromosomally encoded but plasmid mediated quinolone resistance (PMQR) has been reported to occur by three (3) mechanisms which are: (i) a target-protective mechanism encoded by the $q n r$ genes [16] (ii) a dual antibioticmodifying enzyme that acetylates aminoglycosides, but also ciprofloxacin and norfloxacin encoded by the aac( $\left.6^{\prime}\right)-I b-c r$ gene [17] and (iii) an efflux pump encoded by the qep $A$ gene [18]. 
Citation: Ezeh PA, Tende M, Bolaji RO, Olayinka BO, Menegbe BY, et al. (2017) Prevalence of Aac(6')-lb-Cr and Qepa Genes among Quinolone Resistant Uropathogens Isolated from Asymptomatic Female Students of a Northern University on Nigeria. Clin Microbiol 6: 298. doi: $10.4172 / 2327-5073.1000298$

Page 2 of 5

Although PMQR confer low level resistance to quinolones and/or flouroquinolones, they may provide a favorable background where the selection of additional chromosomally-encoded quinolone resistance mechanisms can take place [19]. Plasmid-mediated quinolone resistance gene determinant cause decreased quinolone susceptibility and lead to higher minimum inhibitory concentrations [20]. Transferable quinolone resistance due to the dissemination of $P M Q R$ genes may have important impacts in terms of infection control and treatment problems. Survey of plasmid mediated quinolone resistance will help to determine the size of the problems caused by $P M Q R$ in terms of treatment and infection control and guide the measures that should be taken to avoid escalation of resistance and dissemination of the problem especially in this area. Hence there is need to investigate the prevalence of $a a c\left(6^{\prime}\right)-I b-c r$ and $q e p A$ gene among Enterobateriaceae isolates in the study population.

\section{Methods}

The study was carried out in the Ahmadu Bello University Main Campus Zaria and the study population was the female students who reside in the female hostels in the University within the Campus. Female students who gave their consent were included in this study.

\section{Sample collection}

A total of 400 female students were sampled. A structured selfadministered questionnaire was issued out as the collection containers were being given out so as to obtain demographic data. Midstream, clean-catch urine samples were collected into sterile containers from asymptomatic female students, samples were cultured on growth media (Cystein Electrolyte-Deficient Agar, MacConkey Agar and Eosine Methylene Blue Agar) to determine significant bacteriuria (growth culture of $\geq 10^{5} \mathrm{cfu} / \mathrm{ml}$ ). Isolates from positive sample cultures were sub-cultured onto nutrient agar plates and incubated at $37^{\circ} \mathrm{C}$ for $24 \mathrm{~h}$, after which colonies were identified using MicrogenTM GNA ID Kit and kept in Nutrient agar slants for further analysis.

\section{Antibiotics susceptibility testing}

Antibiotic susceptibility testing was carried out by the modified Kirby-Bauer agar disc diffusion technique as described by [21]. The Quinolones used in this study include Ciprofloxacin, Pefloxacin, Levofloxacin and Norfloxacin. A suspension of overnight growth of each isolate on Nutrient agar plates was standardized by comparing the turbidity with 0.5 McFarland standards corresponding to approximately $1.5 \times 10^{8} \mathrm{cfu} / \mathrm{ml}$. Suspension of the isolates was inoculated on Mueller Hinton agar plate using a sterile swab. The swab was streaked evenly over the surface of the medium to ensure confluent growth. The surface of the agar was allowed to dry for 3-5 min and the antibiotic discs were placed on the surface of the agar using a sterile forcep. Within $30 \mathrm{~min}$ of applying the discs, plates were inverted and incubated at $35^{\circ} \mathrm{C}$ for $16-18 \mathrm{~h}$. After overnight incubation, plates were examined and the diameter of each zone of growth inhibition around the discs was measured in $\mathrm{mm}$, using a ruler on the underside of the plate. Using the Interpretative Chart [21], the zone sizes of each antimicrobial were interpreted and the organism was reported as 'Resistant', 'Intermediate/Moderately susceptible'or 'Susceptible'

\section{Plasmid curing}

Isolates resistant to quinolones were cured of plasmid using acridine orange to determine if resistance is borne on plasmid [22]. Nutrient broth was prepared and supplemented with $0.1 \mathrm{mg} / \mathrm{ml}$ acridine orange. Overnight culture of the bacteria was subcultured into $5 \mathrm{ml}$ of the nutrient broth containing acridine orange. The samples were then incubated at $37^{\circ} \mathrm{C}$ for $24 \mathrm{~h}$. After $24 \mathrm{~h}$ incubation, the isolates were subcultured onto Mueller Hinton agar and quinolone antibiotic discs (Ciprofloxacin, Pefloxacin, Norfloxacin and Levofloxacin) were used to determine the antibiotic susceptibility profile of the isolate after curing using disc diffusion method. Plates were incubated at $37^{\circ} \mathrm{C}$ for $24 \mathrm{~h}$. Measurement of diameters of zones of inhibition were taken and recorded according to [21].

\section{Molecular analysis}

The isolates which were positive for plasmid curing were used for molecular analysis. DNA was extracted by alkaline lysis technique. The Zymo DNA Extraction Kit was used. DNA extraction was carried out by the alkaline lysis technique. The extracted DNA was isolated using horizontal $1 \%$ agarose gel electrophoresis. The pelleted bacterial cells were re-suspended and subjected to sodium dodecyl sulfate (SDS)/ alkaline lysis to liberate the DNA. The resulting lysate was neutralized to create appropriate condition for binding of DNA on the silica membrane in the spin column. Cell debris and SDS precipitate were pelleted by centrifugation, and the supernatant containing the DNA was loaded onto the spin column membrane. The absorbed DNA was washed to remove contaminants, and this was then eluted with a small volume of the elution buffer (10 mM Tris- $\mathrm{HCl}, \mathrm{pH} 8.5)$. The purified DNA was used for all molecular biology procedures (Polymerase chain reaction).

\section{Detection of Quinolone Resistance Genes (aac (6 $\left.6^{\prime}\right) I b$-cr and qepA)}

The $q e p A$ and $a a c\left(6^{\prime}\right) 1 b$-cr genes were amplified using PCR. Gene detection was carried out using PCR techniques as described by [19]. Amplification of resistant DNA fragments was carried out using Dream TaqTM DNA polymerase, which is an enhanced multiplex PCR Taq DNA polymerase, optimized for all standard PCR applications as described by DNeasy Blood and Tissue Handbook (2006): Dream TaqTM PCR master mix (2X) was vortexed and centrifuged for $30 \mathrm{~s}$ at $8000 \mathrm{rpm}$ after thawing. The thin walled PCR tube was then placed on an ice pack and the following components was added for each isolate for single reaction: (a) Dream TaqTM PCR master mix (b) Forward primers (c) reverse primers (d) template DNA, Taq buffer, dNTP (e) the nuclease - free water. The samples were vortexed gently and spin down. The primers to be used for PCR are as contained in the Tables $1-3$.

\begin{tabular}{|l|l|l|l|l|}
\hline $\begin{array}{l}\text { Primer } \\
\text { name }\end{array}$ & Sequence $\left(\mathbf{5}^{\prime} \rightarrow \mathbf{3}^{\prime}\right)$ & $\begin{array}{l}\text { Target } \\
\text { gene(s } \\
\text { ) or } \\
\text { region }\end{array}$ & $\begin{array}{l}\text { PCR } \\
\text { produc } \\
\mathbf{t} \text { size } \\
(\mathbf{b p})\end{array}$ & $\begin{array}{l}\text { Reference } \\
\mathbf{s}\end{array}$ \\
\hline $\begin{array}{l}\text { aaclb- } \\
\text { F }\end{array}$ & TTGCGATGCTCTATGAGTGGCTA & $\begin{array}{l}\text { aac } \\
\left(6^{\prime}\right)-I b\end{array}$ & 482 & {$[17]$} \\
\hline $\begin{array}{l}\text { aaclb- } \\
\text { R }\end{array}$ & CTCGAATGCCTGGCGTGTTT & qepA & 199 & \\
\hline qepA-F & GCAGGTCCAGCAGGGGTAG & & & \\
\hline
\end{tabular}


Citation: Ezeh PA, Tende M, Bolaji RO, Olayinka BO, Menegbe BY, et al. (2017) Prevalence of Aac(6')-lb-Cr and Qepa Genes among Quinolone Resistant Uropathogens Isolated from Asymptomatic Female Students of a Northern University on Nigeria. Clin Microbiol 6: 298. doi: $10.4172 / 2327-5073.1000298$

Page 3 of 5

\begin{tabular}{|l|l|l|l|l|}
\hline $\begin{array}{l}\text { qepA- } \\
\mathrm{R}\end{array}$ & CTT CCTGCCCGAGTATCGTG & & & \\
\hline
\end{tabular}

Table 1: Primers for aac ( $\left.6^{\prime}\right)$-Ib-cr and $q e p A$ genes.

\begin{tabular}{|l|l|l|l|}
\hline STEP & TEMPERATURE $\left({ }^{\circ} \mathrm{C}\right)$ & TIME & $\begin{array}{l}\text { NUMBER OF } \\
\text { CYCLES }\end{array}$ \\
\hline $\begin{array}{l}\text { Initial lysing of } \\
\text { cells }\end{array}$ & 94 & $45 \mathrm{~s}$ & 1 \\
\hline Denaturation & 94 & $45 \mathrm{~s}$ & 34 \\
\hline Annealing & 55 & $45 \mathrm{~s}$ & 1 \\
\hline Extension & 72 & $45 \mathrm{~s}$ & 1 \\
\hline Final extension & 72 & $5 \mathrm{~min}$ & 1 \\
\hline Final hold & 4 & & \\
\hline
\end{tabular}

Table 2: PCR run conditions for the aac (6') $1 b$-cr primers [17].

\begin{tabular}{|l|l|l|l|}
\hline STEP & TEMPERATURE $\left({ }^{\circ} \mathbf{C}\right)$ & TIME & $\begin{array}{l}\text { NUMBER OF } \\
\text { CYCLES }\end{array}$ \\
\hline $\begin{array}{l}\text { Initial lysing of } \\
\text { cells }\end{array}$ & 96 & $1 \mathrm{~min}$ & 1 \\
\hline Denaturation & 96 & $1 \mathrm{~min}$ & 30 \\
\hline Annealing & 60 & $1 \mathrm{~min}$ & 1 \\
\hline Extension & 72 & $1 \mathrm{~min}$ & 1 \\
\hline Final extension & 72 & $5 \mathrm{~min}$ & 1 \\
\hline Final hold & 4 & & \\
\hline
\end{tabular}

Table 3: PCR run conditions for the qepA primers.

\section{Results}

A total of $63 / 400(16 \%)$ of the urine samples from female students had significant bacteriruia (bacterial count $\geq 10^{5} \mathrm{cfu} / \mathrm{ml}$ ). A total of 148 bacterial isolates were recovered from the 63 urine samples with significant bacteriuria. The organisms consisted mainly of Klebsiella spp. (19.6\%), Acinetobacter spp. (19.6\%), Enterobacter spp. (17.6) and Escherichia spp. (11.5\%) (Table 4).

\begin{tabular}{|l|l|}
\hline ISOLATES & Number (\%) \\
\hline Klebsiella spp. & $29(19.59)$ \\
\hline Acinetobacter spp. & $29(19.59)$ \\
\hline Enterobacter spp. & $26(17.57)$ \\
\hline Escherichia spp. & $17(11.49)$ \\
\hline Salmonella spp. & $14(9.46)$ \\
\hline Serratia spp. & $13(8.78)$ \\
\hline Proteus spp. & $8(5.40)$ \\
\hline Citrobacter spp. & $6(4.05)$ \\
\hline Yersinia spp. & $3(2.03)$ \\
\hline
\end{tabular}

\begin{tabular}{|l|l|}
\hline Providencia spp. & $2(1.35)$ \\
\hline Shigella spp. & $1(0.68)$ \\
\hline Total & $148(100)$ \\
\hline
\end{tabular}

Table 4: Distribution of isolates to genus level using MicrogenTM GNA-ID KIT.

A total of $18 / 148(12.2 \%)$ of the isolates showed resistance to quinolones. The highest level of resistance to Quinolones was observed with Ciprofloxacin (12\%) (Figure 1), and the quinolone resistant isolates were cured of plasmids using acridine orange. 10 (55.6\%) of the isolates showed increased susceptibility to the same quinolone antibiotics used for antibiotic susceptibility testing to which they were resistant.

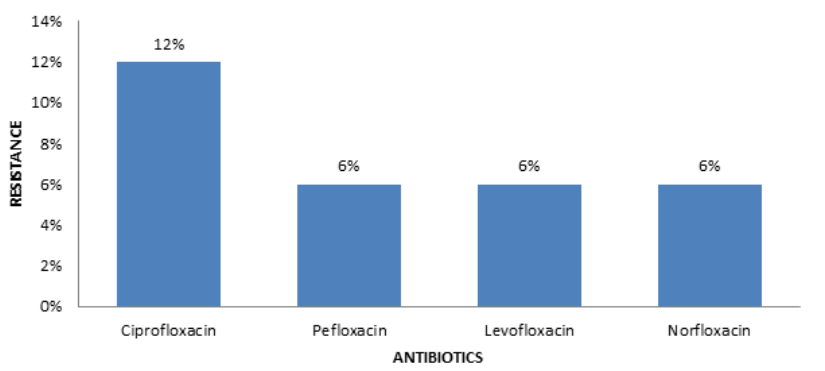

Figure 1: Percentage Resistance of Uropathogen to Quinolones.

Molecular analysis showed the amplification aac $\left(6^{\prime}\right)-I b$-cr gene and $q e p A$ gene on electrophoretic gel. 70\% (7/10) of the isolates expressed the gene $a a c\left(6^{\prime}\right)-I b-c r$ of 482 bp and $70 \%(7 / 10)$ of the isolates expressed the gene qepA of 199 bp on electrophoretic gel (Figures 2 and 3) (Tables 5 and 6).

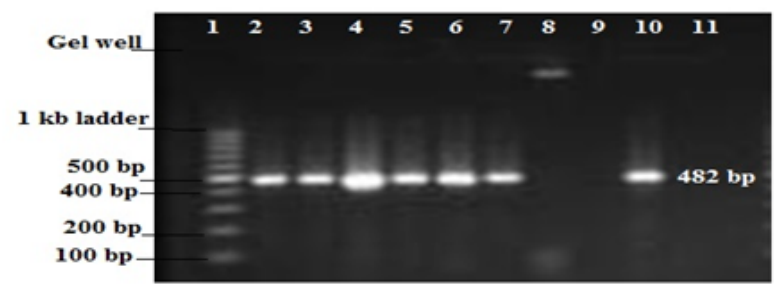

Figure 2: Molecular Characterization of $a a c\left(6^{\prime}\right)-I b-c r$ Genes (482 bp).

\begin{tabular}{|l|l|l|}
\hline $\begin{array}{l}\text { LANES (Refer } \\
\text { Figure 2) }\end{array}$ & ISOLATE CODE & AMPLIFIED GENE \\
\hline 1 & Gel ladder & - \\
\hline 2 & $84(1)$ & Has aac(6')-Ib-cr gene \\
\hline 3 & $51(1)$ & Has aac(6')-Ib-cr gene \\
\hline 4 & $46(1)$ & Has aac(6')-Ib-cr gene \\
\hline
\end{tabular}


Citation: Ezeh PA, Tende M, Bolaji RO, Olayinka BO, Menegbe BY, et al. (2017) Prevalence of Aac(6')-lb-Cr and Qepa Genes among Quinolone Resistant Uropathogens Isolated from Asymptomatic Female Students of a Northern University on Nigeria. Clin Microbiol 6: 298. doi: $10.4172 / 2327-5073.1000298$

Page 4 of 5

\begin{tabular}{|c|c|c|}
\hline 5 & $51(3)$ & Has aac $\left(6^{\prime}\right)-I b-c r$ gene \\
\hline 6 & $28(2)$ & Has aac $\left(6^{\prime}\right)-I b$-cr gene \\
\hline 7 & $83(1)$ & Has aac $\left(6^{\prime}\right)-I b$-cr gene \\
\hline 8 & $65(2)$ & - \\
\hline 9 & $306(2)$ & - \\
\hline 10 & 327 (1) & Has aac $\left(6^{\prime}\right)-I b-c r$ gene \\
\hline 11 & $46(2)$ & - \\
\hline
\end{tabular}

Table 5: Molecular Characterization of $a a c\left(6^{\prime}\right)-I b-c r$ Genes (482 bp).

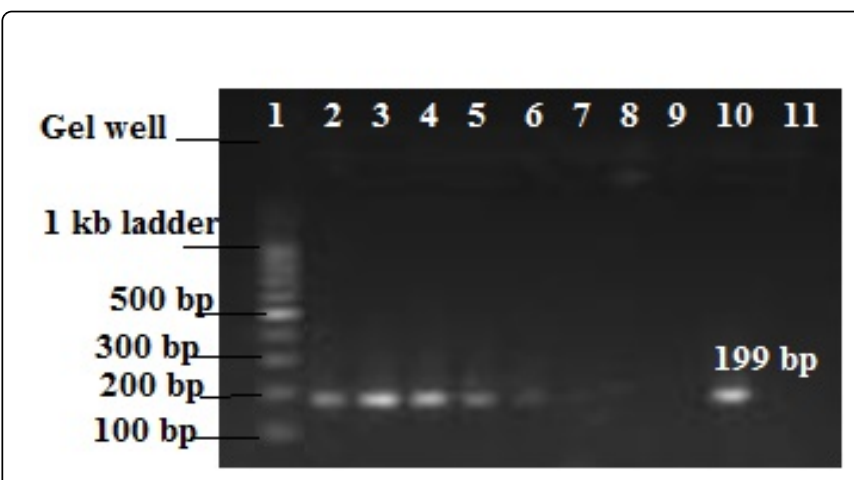

Figure 3: Molecular Characterization of qepA Genes (199 bp).

\begin{tabular}{|l|l|l|}
\hline LANES (Refer figure 3) & ISOLATE CODE & AMPLIFIED GENE \\
\hline 1 & Gel ladder & - \\
\hline 2 & $84(1)$ & Has qepA gene \\
\hline 3 & $51(1)$ & Has qepA gene \\
\hline 4 & $46(1)$ & Has qepA gene \\
\hline 5 & $51(3)$ & Has qepA gene \\
\hline 6 & $28(2)$ & Has qepA gene \\
\hline 7 & $83(1)$ & Has qepA gene \\
\hline 8 & $65(2)$ & - \\
\hline 9 & $306(2)$ & - \\
\hline 10 & $327(1)$ & Has qepA gene \\
\hline 11 & $46(2)$ & - \\
\hline
\end{tabular}

Table 6: Molecular Characterization of qepA Genes (199 bp).

\section{Discussion}

The antibiotic susceptibilities of the isolated organisms are helpful in determining the appropriate antibiotics. The antibiotics that are commonly prescribed for the treatment of infections associated with uropathogens include Ciprofloaxcin, Cotrimoxazole, Amoxicillin/ Clavulanic Acid and Nitrofurantoin [23]. In this study, quinolones/ fluoroquinolones had great activity against the isolates with only $12.2 \%$

resistant to the agents and this agrees with the report of other researchers [24,25] who reported Ciprofloxacin as the most effective antibiotic against isolates from asymptomatic bacteriuria. Ciprofloxacin has been recorded to be effective across the board and is recommended for treatment of UTI when other drugs have failed [26].

Evaluation for the presence of antibiotic resistance genes from the 10 quinolone resistant isolates from asymptomatic bacteriuria subjects was carried out using molecular techniques. Ten (10) of the isolates selected for DNA extraction were found to carry plasmid mediated quinolone resistance genes. To validate most reports that quinolone resistance are encoded by plasmids [9,13,27], the results of the antibiotics susceptibility profile to quinolones of the quinolone resistant isolates were compared before and after curing using acridine dye. The result showed that $10(55.6 \%)$ of the quinolone resistant isolates became sensitive to the quinolones tested after exposure to acridine dye. This result suggests that the resistant determinants to the quinolone antibiotics might be plasmid encoded, which became cured in the presence of acridine dye [28].

Plasmid-mediated quinolone resistance (PMQR) genes code for low levels of quinolone resistance [29]. The presence of PMQR gene in resistant isolates was $6.75 \%$. This agrees with other studies that reported prevalenece of PMQR gene [30,31].

Molecular characterization of plasmid-mediated quinolone resistance (PMQR) genes in quinolone resistant asymptomatic bacteriruia isolates showed that aac (6')-Ib-cr (70\%) and qepA (70\%) genes were the most prevalent genes among quinolone resistant isolates in Zaria These findings agrees with the report of Cruz et al. [32] who isolated $a a c\left(6^{\prime}\right)-I b-c r$ and $q n r B$ genes from enterobacteriaceae. The $a a c\left(6^{\prime}\right)-I b-c r$ enzyme reduces only ciprofloxacin and norfloxacin activity by acetylation [17], the result of this study showed that all the isolates carrying the $a a c\left(6^{\prime}\right)-I b-c r$ gene were resistant to Ciprofloxacin and/or Norfloxacin.

A study by Wang et al. [13] reported a high prevalence of $a a c\left(6^{\prime}\right)-I b$ cr gene (77.5\%) among E. coli and Klebsiella pneumoniae isolates. Also a study by [31] recorded aac ( $\left.6^{\prime}\right)$-Ib-cr gene (95\%) as the most common PMQR gene isolated from multidrug resistant E. coli in India. This agrees with the result obtained in this study as a high prevalence of isolation of the $a a c\left(6^{\prime}\right)-I b-c r$ was recorded. $Q e p A$ gene is a quinolone pump gene that confers resistance to nalidixic acid and norfloxacin. Strains carrying this gene may be resistant or sensitive to ofloxacin and ciprofloxacin with increased MIC [13]. QepA gene has also been isolated from Enterobateriaceae [13,33]. Presence of these genes among healthy populations can cause treatment of infection caused by Enterobacteriaceae difficult as multidrug resistance is likely.

\section{Conclusion}

The distribution of drug resistance and PMQR genes aac(6')-Ib-cr and qep $A$ among Enterobacteriaceae isolates can limit therapeutic options and this is a great concern.

\section{Recommendation}

There is an incidence of PMQR among the studied population. Therefore, it is necessary to monitor for the spread of PMQR genes of asymptomatic bacteriuria isolates and to ensure careful antibiotic use among students and in a hospital setting. 
Citation: Ezeh PA, Tende M, Bolaji RO, Olayinka BO, Menegbe BY, et al. (2017) Prevalence of Aac(6')-lb-Cr and Qepa Genes among Quinolone Resistant Uropathogens Isolated from Asymptomatic Female Students of a Northern University on Nigeria. Clin Microbiol 6: 298. doi: $10.4172 / 2327-5073.1000298$

Page 5 of 5

\section{References}

1. Hopkins KL, Davies RH, Threlfall JE (2005) Mechanisms of quinolone resistance in Escherichia coli and Salmonella: Recent developments. Int J Antimicrob Agents, 25: 358-373.

2. Ball P (2000) Quinolone generations: natural history or natural selection?. J Antimicrob Chemother 46:17-24.

3. Panton JH, Reeves DS (1988) Floroquinolone antibiotic: microbiology, Pharmacokinetics and Clinical use. Drugs 36:193-228.

4. Korstanje-Hoogkamp JA (1997) In vitro activities of ciprofloxacin levofloxacin, lomefloxacin, ofloxacin, pefloxacin, sparfloxacin and trovafloxacin against Gram-positive and Gram-negative pathogens from respiratory tract infections. J Antimicrob Chemother 40: 427-431.

5. Hooper DC (2005) Douglas and Bennett's Principles and Practices of Infectious Diseases 6th ed Elseiver/Churchill Livingstone New York.

6. Hooper DC (2001) Emerging mechanisms of fluoroquinolone resistance. Emerg Infect Dis 7: 337-41.

7. Cottell JL, Webber MA, Coldham NG, Taylor DL, Cerdeno-Tarraga AM, et al. (2011) CompleteSequence and Molecular Epidemiology of IncK Epidemic Plasmid Encoding blaCTX-M-14. Emerg Infect Dis 17: 645-652

8. Daini OA, Olukoya DK, Ogunjima AA (1995) Genetic analysis of tetracycline resistance plasmids in enteropathogenic E coli isolated from patients in Nigeria. J Diarrhoeal Dis Res 13: 39-43.

9. Tran JH, Jacoby GA (2002) Mechanism of plasmid-mediated quinolone resistance. , 99: 5638-5642.

10. Rafael TT, Braun SS, Puhler A, Schluter A (2003) Occurrence of integronassociated resistance gene cassettes located on antibiotic resistance plasmids isolated from a wastewater treatment plant. FEMS Microbiol Ecol 45: 239-252

11. Igwe JC, Onaolapo JA, Dauda EO, Oladipo HO (2013) Plasmid Conjugation in E. coli and Drug Resistance. Nig J Biotech 26: 41-49.

12. Oni AA, Bakere RA, Arowojolu OA, Kehinde OA, Toki RA, et al. (2001) Comparative in vitro activities of commonly available quinolones and other antibiotics in bacterial isolates in Ibadan Nigeria. Afr J Med Sci 30: 35-37.

13. Wang D, Huang X, Chen J, Mou Y, Li H, et al. (2015) Characterization of genetic structures of the qepA gene in clinical isolates of enterobateriaceae. Front Microbiol 6: 1147.

14. Daini OA, Ogbolu OD, Ogunledun A (2005) Quinolones resistance and R-plasmids of some gram negative enteric bacilli. Afr J Clin Exp Microbiol 6: 14-20.

15. Nordmann P, Poirel L (2005) Emergence of plasmid-mediated resistance to quinolones in Enterobacteriaceae. J Antimicrob Chemother 56: 463-469.

16. Martinez-Martinez L, Pascual A, Jacoby GA (1998) Quinolone resistancefrom a transferable plasmid. Lancet 351: 797-799.

17. Park CH, Robicsek A, Jacoby GA, Sahm D, Hooper DC (2006) Prevalence in the United States of aac(6_)-Ib-cr encoding a ciprofloxacinmodifying enzyme. Antimicrob Agents Chemother 50: 3953-3955.

18. Perichon B, Courvalin P, Galimand M (2007) Transferable resistance to aminoglycosides by methylation of G1405 in $16 \mathrm{~S}$ rRNA and to hydrophilic fluoroquinolones by QepA mediated efflux in Escherichia coli. Antimicrob Agents Chemother 51: 2464-2469.

19. Poirel L, Cattoir V, Nordmann P (2008) Is plasmid-mediated quinolone resistance a clinically significant problem? Clin Microb Infect 14: 295-297.

20. Coban AY, Nohut OK, Tanrivri CY, Bayramoglu G, Pirincciler M, et al. (2012) Investigation of plasmid-mediated quinolone resistance determinants in Enterobactericeae: a multicenter study. Microbiol Bulletin 46: 366-74.

21. Clinical and Laboratory Standards Institute (2014) Performance Standards for Antimicrobial Susceptibility Testing; Twenty-Fourth Informational Supplement. 950 West Valley Road, Suite 2500 Wayne, PA 19087 USA.

22. Brown TA (2000) Essential Molecular Biology, A Practical Approach. Oxford University Press 2nd Ed 1: 69-102.

23. Shoff WH (2014) Asymptomatic bacteriuria. Drugs and Diseases Medscape.

24. Orrett FA, Davis GK (2006) A comparison of antimicrobial susceptibility profile of urinary pathogens for the years, 1999 and 2003. West Indian Med J 55: 95-9.

25. Mansour A, Manijeh M, Zohreh P (2009) Study of bacteria isolated from urinary tract infections and determination of their susceptibility to antibiotics. Jundishapur J Microbiol 2: 118-123.

26. Stamm WE, Norrby SR (2001) Urinary tract infection: Disease panorama and challenges. J Infect Dis 183: S1-S4.

27. Strahilevitz J, Jacoby GA, Hooper DC, Robicsek A (2009) Plasmid mediated quinolone resistance: a multifaceted threat. Clin Microbiol Rev 22: 664-689.

28. Hadis D, Majid B, Amir E (2015) Plasmid Curing Assay in Clinical Isolates of Antibiotic Resistant Acinetobacter baumannii. Microbiol J 5: 43-48.

29. El Salabi A, Walsh TR, Chouchani C (2013) Extended spectrum betalactamases, carbapenemases and mobile genetic elements responsible for antibiotics resistance in gram negative bacteria. Crit Rev Microbiol 39: 113-122.

30. Kim HB, Park CH, Kim CJ, Kim E, Jacoby GA, et al. (2009) Prevalence of Plasmid-Mediated Quinolone Resistance Determinants over a 9-Year Period. Antimicrob Agents Chemother 53: 639-645

31. Pathak A, Chandran SP, Mahadik K, Macaden R, Lundborg CS (2013) Frequency and factors associated with carriage of multi-drug resistant commensal E. coil among women attending antenantal clinics in central India. BMC Infect Dis 13: 199.

32. Cruz GR, Radice M, Sennati S, Pallecchi L, Rossolini GM, et al. (2013) Prevalence of plasmid-mediated quinolone resistancedeterminants among oxyiminocephalosporin-resistant Enterobacteriaceae in Argentina. Mem Inst Oswaldo Cruz 108: 924-927.

33. Hassan WM, Hashim A, Domany RAA (2012) Plasmid mediated quinolone resistance determinants qnr, acc (6)-ib-cr, and qep IN esblProducing E.coli clinical isolates from Egypt. Indian J Med Microbiol 30: 442-447. 